\title{
A comparative study of the acute toxicity of the herbicide atrazine to cladocerans Daphnia magna, Ceriodaphnia silvestrii and Macrotbrix flabelligera
}

Um estudo comparativo da toxicidade aguda do herbicida atrazina aos cladóceros Daphnia magna, Ceriodaphnia silvestrii e Macrothrix flabelligera

\author{
Raquel Aparecida Moreira, Adrislaine da Silva Mansano, \\ Lidiane Cristina da Silva and Odete Rocha
}

\begin{abstract}
Programa de Pós-graduação em Ecologia e Recursos Naturais, Universidade Federal de São Carlos - UFSCar, Rodovia Washington Luiz, Km 235, CP 676, Bairro Monjolinho, CEP 13565-905, São Carlos, SP, Brazil e-mail: raquel.moreira87@yahoo.com.br; laine_mansano@yahoo.com.br; lidianecris2004@yahoo.com.br; doro@ufscar.br
\end{abstract}

\begin{abstract}
Aim: In this study we compared the sensitivity of three species of Cladocera, Daphnia magna, Ceriodaphnia silvestrii and Macrothrix flabelligera, to the commercial product of the herbicide Atrazine, the Atrazine Atanor 50 SC $(500 \mathrm{~g} / \mathrm{L})$, widely used on crops in Brazil. Methods: Acute toxicity tests were performed at the nominal atrazine concentrations $2.25,4.5,9.0,18.0,36$ and $72 \mathrm{mg} \mathrm{L}^{-1}$, on $C$. silvestrii and $M$. flabelligera and at 2.25, 4.5, 9.0, 18.0,36, 72 and $144 \mathrm{mg} \mathrm{L}^{-1}$ on D. magna. The range of concentrations tested was established in a series of preliminary tests. Results: The toxicity tests showed that the two species naturally occurring in water bodies in Brazil were more susceptible than Daphnia magna. The effective concentrations of Atrazine Atanor $50 \mathrm{SC}^{\circ}$ $\left(\mathrm{EC}_{50}-48 \mathrm{~h}\right.$ ) to the species $M$. flabelligera, C. silvestrii and D. magna were $12.37 \pm 2.67$ $\mathrm{mg} \mathrm{L}^{-1}, 14.30 \pm 1.55 \mathrm{mg} \mathrm{L}^{-1}$ and $50.41 \pm 2.64 \mathrm{mg} \mathrm{L}^{-1}$, respectively. Furthermore, when $\mathrm{EC}_{50}$ observed here for $M$. flabelligera and $C$. silvestrii were compared with published values of $\mathrm{EC}_{50}$ or $\mathrm{LC}_{50}\left(\mathrm{mg} \mathrm{L}^{-1}\right)$ for various aquatic organisms exposed to atrazine, it was seen that these two cladocerans were the most sensitive to the herbicide. Conclusions: Considering these results and the broad distribution of C. silvestrii and M. flabelligera in tropical and subtropical regions, it is concluded that these native species would be valuable test organisms in ecotoxicological tests, for the monitoring of toxic substances in tropical freshwaters.
\end{abstract}

Keywords: Cladocera, Ecotoxicology, Atrazine Atanor 50 SC, pesticide.

Resumo: Objetivo: Neste estudo comparamos a sensibilidade de três espécies de cladóceros, Daphnia magna, Ceriodaphnia silvestrii e Macrothrix flabelligera quando expostas ao herbicida Atrazina Atanor $50 \mathrm{SC}^{\oplus}(500 \mathrm{~g} / \mathrm{L})$, amplamente utilizado em plantações no Brasil. Métodos: Foram realizados testes de toxicidade aguda das concentraçóes nominais de atrazina nos valores de 2,25; 4,5; 9,0; 18,0; 36 e $72 \mathrm{mg} \mathrm{L}^{-1}$ para C. silvestrii e $M$. flabelligera e de 2,25; 4,5; 9,0; 18,0;36; 72 e $144 \mathrm{mg} \mathrm{L}^{-1}$ para D. magna. Estas faixas de concentraçóes foram estabelecidas em testes preliminares. Resultados: Os testes de toxicidade mostraram que as duas espécies que ocorrem naturalmente nos corpos d'água do Brasil foram mais sensíveis do que Daphnia magna. As concentraçōes efetivas de Atrazina Atanor $50 \mathrm{SC}^{\ominus}\left(\mathrm{CE}_{50}-48 \mathrm{~h}\right)$ para M. Alabelligera, C. silvestrii e D.magna, foram $12.37 \pm 2.67 \mathrm{mg} \mathrm{L}^{-1}, 14.30 \pm 1.55 \mathrm{mg} \mathrm{L}^{-1}$ e $50.41 \pm 2.64$ $\mathrm{mg} \mathrm{L} \mathrm{L}^{-1}$, respectivamente. Comparando-se os valores de $\mathrm{CE}_{50}$ da atrazina obtidos para $M$. flabelligera e C. silvestrii com valores de $\mathrm{CE}_{50}$ ou $\mathrm{CL}_{50}\left(\mathrm{mg} \mathrm{L}^{-1}\right)$ disponíveis na literatura para diferentes organismos aquáticos observa-se que os cladóceros testados foram mais sensíveis ao herbicida do que os demais. Conclusóes: Com base nestes resultados e considerando-se a ampla distribuição de C. silvestrii e $M$. flabelligera em regióes tropicais e subtropicais, conclui-se que estas espécies nativas são importantes organismos-teste a serem utilizados em ensaios ecotoxicológicos para o monitoramento de toxicidade nas águas doces tropicais.

Palavras-chave: Cladocera, Ecotoxicologia, Atrazina Atanor 50 SC, pesticida. 


\section{Introduction}

The number of synthetic chemical substances has greatly expanded over the last few decades. Large quantities of toxic chemicals are released into the environment, contaminating air, soil and water (Bonaventura and Johnson, 1997). Among the numerous chemicals that reach bodies of freshwater, pesticides have particularly serious effects on the aquatic biota and can lead to great losses in biodiversity (Grützmacher et al., 2008; AguilarAlberola and Mesquita-Joanes, 2012).

The increasing world population and corresponding demand for food has encouraged the expansion of agribusiness and motivated the use of large quantities of herbicides on crops, to decrease damage caused by weeds and thus boost productivity. The herbicide atrazine, which is an inhibitor of photosynthesis, is also an artificial compound classified as a potential endocrine disruptor that may act by stimulating the activity of the aromatase enzyme that converts testosterone to estrogen (Sanderson et al., 2000). In the tropics, owing to its relatively free mobility in the soil and the frequently torrential rains in the summer, most of the atrazine applied to crops is leached out and, consequently, residues are found in various environments, especially in surface water and groundwater (Gilliom et al., 2006; Wightwick and Allinson, 2007).

Cladocerans are an important component of the zooplankton. They consume phytoplankton and are, in turn, heavily preyed upon by larval fish (Dettmers and Stein, 1992). The use of cladocerans in toxicity tests has many advantages, including their ease of handling, the possibility of obtaining clones by parthenogenesis, their short life cycle and high sensitivity to toxicants. These characteristics make them suitable test organisms for bioassays (Adema, 1978; Trayler and Davis, 1996). The cladoceran most commonly used in aquatic ecotoxicology is undoubtedly Daphnia magna (Baillieul and Blust, 1999; Biesinger and Christensen, 1972; Lilius et al., 1995; Winner and Farrell, 1976). However, the natural geographical distribution of this species is restricted to areas of northern high and mid-latitudes (Mitchell et al., 2004). The use of such temperate species in tropical regions for ecotoxicological assessments seems inappropriate, since the toxic responses of organisms to chemicals are often species-specific.

Acute toxicity of the herbicide atrazine to several other species belonging to different taxonomical groups can be found in the literature in relation to mortality, expressed as $\mathrm{LC}_{50}$ of atrazine: $17.1 \mathrm{mg}$ $\mathrm{L}^{-1}$ to the cladoceran Pseudosida ramosa (Freitas and Rocha, 2011); $33.0 \mathrm{mg} \mathrm{L}^{-1}$ to the amphipod Hyalella azteca (Wan et al., 2006); $36.7 \mathrm{mg} \mathrm{L}^{-1}$ to the anostracean Thamnocephalus platyurus (Palma et al., 2008); $18.9 \mathrm{mg} \mathrm{L}^{-1}$ to the amphibian Rana catesbeiana (Taylor et al., 1991); over $480 \mathrm{mg}$ $\mathrm{L}^{-1}$ (Wan et al. 2006) and $48.0 \mathrm{mg} \mathrm{L}^{-1}$ to the fish Oncorhynchus kisutch (Wan et al., 2006). In relation to the other parameters as growth inhibition after 72 hours of exposure a $\mathrm{LC}_{50}$ of $0.196 \mathrm{mg} \mathrm{L}^{-1}$ of atrazine was found to the algae Raphidocelis subcapitata, according to Pérez et al. (2011). In relation to luminescence inhibition to the bacterium Vibrio fischeri Palma et al. (2008) obtained $\mathrm{LC}_{50}$ values of $69.4 \mathrm{mg} \mathrm{L}^{-1}$.

With this study we intend to extend the knowledge particularly regarding the effects of atrazine upon non-target freshwater invertebrates, evaluating its acute toxicity effects on two Neotropical native species occurring in Brazil.

Thus, in the present study we used the cladocerans Daphnia magna, Ceriodaphnia silvestrii and Macrothrix flabelligera to test the acute effects of the commercial product Atrazine Atanor 50 SC, with the goal of determining the acute toxicity of atrazine to cladocerans and comparing the results obtained for Daphnia magna with those for species Ceriodaphnia silvestrii and Macrothrix flabelligera occurring in Brazilian freshwaters, leading to a discussion of the importance of using native species in ecotoxicological monitoring.

\section{Material and Methods}

\subsection{Organism and culture conditions}

The cladoceran Daphnia magna is an exotic planktonic microcrustacean widely distributed in the northern hemisphere, measuring 3 to $6 \mathrm{~mm}$ in length (ABNT, 2004; Koivisto, 1995). The species Ceriodaphnia silvestrii is a native planktonic microcrustacean, found in Brazil and Argentina, which reaches just 0.8 to $0.9 \mathrm{~mm}$ in length (Fonseca and Rocha, 2004) Macrothrix flabelligera is a nonplanktonic microcrustacean isolated in Australia and Brazil, $1.0 \mathrm{~mm}$ long (Güntzel et al., 2004).

Ceriodaphnia silvestrii was originally isolated from Broa Reservoir, Brotas, SP. Daphnia magna was obtained from the Ecotoxicology Laboratory of the Center for Nuclear Energy in Agriculture (CENA), Piracicaba SP and kept in stock cultures for more than 5 years in the laboratory of Ecotoxicology at the Federal University of São Carlos. Macrothrix 
flabelligera was isolated from experimental tanks of $10.000 \mathrm{~L}$ capacity, maintained at the Aquaculture Station of the Hydrobiology Department at the Federal University of São Carlos, São Carlos, SP.

The cultures of $D$. magna were kept in an incubator at a controlled temperature of $22 \pm 2^{\circ} \mathrm{C}$ and with a $12 \mathrm{~h}$ light: $12 \mathrm{~h}$ dark photoperiod. While C. silvestrii and $M$. flabelligera were kept at $25 \pm 2^{\circ} \mathrm{C}$, with a $16 \mathrm{~h}$ light: $8 \mathrm{~h}$ dark photoperiod.

C. silvestrii and M. flabelligera were cultured in reconstituted soft water, prepared according to ABNT (2005) with the following characteristics: $\mathrm{pH} 7.0$ to 7.8 , hardness between 40 and $48 \mathrm{mg}$ $\mathrm{CaCO}_{3} \mathrm{~L}^{-1}$ and electrical conductivity $160 \mu \mathrm{S} \mathrm{cm}^{-1}$. These two species were kept in $2 \mathrm{~L}$ beakers holding up to 140 individuals.

D. magna was cultured in an artificial culture medium of high hardness (ASTM, 1980), as follows: $\mathrm{pH} 8.0$ to 8.6 and hardness between 180 and 220 $\mathrm{mg} \mathrm{CaCO}_{3} \mathrm{~L}^{-1}$. This species was maintained in beakers of $2 \mathrm{~L}$ holding up to 50 individuals.

Cultures of $C$. silvestrii and $M$. flabelligera were fed with a suspension of the alga Raphidocelis subcapitata, grown in CHU-12 medium (Müller, 1972) to a final density of $1 \times 10^{5}$ cells $\mathrm{mL}^{-1}$, and a feed composed of yeast and fish meal (fermented in the ratio $1: 1$ ) at a concentration of $1 \mathrm{~mL} \mathrm{~L}^{-1}$ (ABNT, 2004). The $D$. magna cultures were fed as described for $C$. silvestrii and $M$. flabelligera, but with twice the quantity of algal suspension $\left(2 \times 10^{5}\right.$ cells $\left.\mathrm{mL}^{-1}\right)$.

The cultures were renewed three times a week, when the water and the food were changed. The health and sensitivity of the test organisms were checked monthly, by performing acute toxicity tests with the reference substance sodium chloride for $C$. silvestrii and potassium dichromate for $D$. magna and M. flabelligera.

\subsection{Acute toxicity tests}

The atrazine herbicide used, Atanor $50 \mathrm{SC}^{\oplus}$ $(500 \mathrm{~g} / \mathrm{L})$, contained $50 \%$ of the active ingredient. This commercial product (soluble in water) was diluted directly in reconstituted water for the tests. The test procedure conformed to the Brazilian Standard Method (ABNT, 2004). The acute toxicity tests consisted in exposing 5 neonates, aged less than 24 hours, in replicate, to a series of nominal concentrations of atrazine $(2.25 ; 4.5 ; 9.0 ; 18.0 ; 36$ and $72 \mathrm{mg} \mathrm{L}^{-1}$ for $C$. silvestrii and $M$. flabelligera and 2.25; 4.5; 9.0; 18.0; 36; 72 and $144.0 \mathrm{mg} \mathrm{L}^{-1}$ for $D$. magna) in $10 \mathrm{ml}$ test solution. The range of concentrations tested was established in a series of preliminary tests. The concentrations were prepared immediately before the tests.

The toxicity tests lasted 48 hours and were performed in cell culture plates with 6 wells $\left(\mathrm{TPP}^{\circledast}\right)$. The control was reconstituted water. Four replicates were done for the control and for each tested concentration of atrazine. The experiments were kept at the same temperature as the stock cultures, without food or light. At the beginning of the tests, the variables $\mathrm{pH}$, conductivity, temperature and hardness were measured in the test-solutions; these variables were measured again at the end of the test (except hardness) for those to which there was not a sufficient volume.

\subsection{Data treatment and statistical analysis}

After the period of exposure (48 hours), the motionless organisms were counted. If the percentage of motionless organisms in the control exceeded $10 \%$, the test would be considered invalid; however, this did not occur in this experiment. The results were expressed as $\mathrm{EC}_{50}(48-\mathrm{h})$ - effective average concentration that causes an acute effect on $50 \%$ of the organisms in the exposure time (ABNT, 2004), with a confidence interval of $95 \%$, using the statistical program Trimmed Spearmann - Karber (Hamilton et al., 1977).

The sensitivity of the three cladoceran species exposed to the herbicide atrazine was evaluated from their performance in three test runs. The results were shown as box-plot graphs in which the upper and lower confidence limits approximately correspond to plus or minus two standard deviations for the mean $\mathrm{EC}_{50}$ 48-h values obtained.

\section{Results}

During the acute toxicity tests for $C$. silvestrii and $M$. flabelligera, the average $\mathrm{pH}$ measured in the test solutions remained within the range from 7.0 to 7.7 and did not vary by more than 1.0 unit in any test, the temperature varied between 24.3 and $25.1^{\circ} \mathrm{C}$, the electrical conductivity between $\mathbf{1 5 2 . 6}$ and $159.2 \mu \mathrm{S} \mathrm{cm}^{-1}$ and the water hardness between 40 and $48 \mathrm{mg} \mathrm{CaCO}_{3} \mathrm{~L}^{-1}$. For the D. magna tests the $\mathrm{pH}$ value stayed within the range 8.1 to 8.5 and did not vary more than 0.5 unit during the test; the temperature varied between 21.6 and $22.9^{\circ} \mathrm{C}$, the electrical conductivity 502 to $552 \mu \mathrm{S} \mathrm{cm} \mathrm{cm}^{-1}$ and the initial hardness varied from 180 to $188 \mathrm{mg} \mathrm{CaCO}_{3}$ $\mathrm{L}^{-1}$. Thus, the toxicity tests fulfilled the validity criteria specified in the guidelines of the Brazilian Association of Technical Standards (ABNT, 2005) for C. silvestrii and of the Organization for 
Economic Cooperation and Development (OECD, $2004)$ for $D$. magna. At the end of the tests, the mortality in the controls never exceeded $10 \%$, as recommended in the OECD guidelines.

The values of $\mathrm{EC}_{50}-48 \mathrm{~h}$ and the respective $95 \%$ confidence intervals (CI), for the three species, of the commercial herbicide atrazine Atanor $50 \mathrm{SC}^{\oplus}$ were calculated separately for each one of the three tests of each species. The $\mathrm{EC}_{50}$ data, $\mathrm{CI}$ and standard deviations are presented in Table 1 . The sensitivity of D. magna was between 45.12 and $55.69 \mathrm{mg} \mathrm{L}^{-1}$, with an average of $50.41 \mathrm{mg} \mathrm{L}^{-1}$; of $C$. silvestrii between 11.20 and $17.39 \mathrm{mg} \mathrm{L}^{-1}$, with an average of $14.30 \mathrm{mg} \mathrm{L}^{-1}$, and of $M$. flabelligera between 7.02 and $17.71 \mathrm{mg} \mathrm{L}^{-1}$, with an average of 12.37 $\mathrm{mg} \mathrm{L}^{-1}$ (Figure 1).

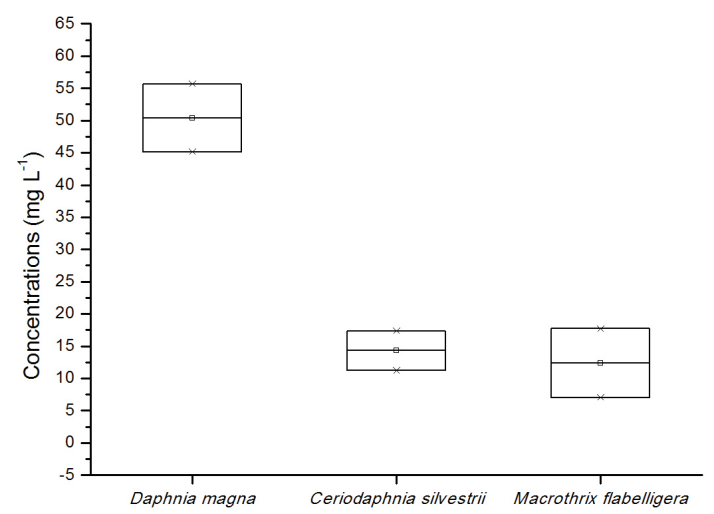

Figure 1. Box-plots representing mean $\mathrm{EC}_{50}$ - $48 \mathrm{~h}$ sensitivity values \pm 2 standard deviations of Daphnia magna, Ceriodaphnia silvestrii and Macrothrix flabelligera to the atrazine Atanor $50 \mathrm{SC}^{\oplus}$ based on three acute toxicity tests.

\section{Discussion}

According to the results, M. flabelligera and $C$. silvestrii showed greater sensitivity to the herbicide Atrazine Atanor SC ${ }^{\oplus}$ than D. magna, since the value of $\mathrm{EC}_{50}-48 \mathrm{~h}$ for $M$. flabelligera was fourfold and C. silvestrii threefold lower than that for D. magna (See Figure 1).

The values of $\mathrm{EC}_{50}$ - $48 \mathrm{~h}$ of atrazine found in the literature for the cladocerans most often used as test-organisms in temperate regions were $24.6 \mathrm{mg}$ $\mathrm{L}^{-1}$ (Phyu et al., 2004), $26.9 \mathrm{mg} \mathrm{L} \mathrm{L}^{-1}$ (Macek et al., 1976, cited in Freitas and Rocha, 2012) and 36.5 $\mathrm{mg} \mathrm{L}^{-1}$ (Hartman and Martin, 1985), for Daphnia carinata, D. magna and $D$. pulex, respectively. Thus, the values of $\mathrm{EC}_{50}-48 \mathrm{~h}$ for the native species (Ceriodaphnia silvestrii and Macrothrix flabelligera) are also lower than those reported for Daphnia magna as well as for other cladoceran species as can be observed in Table 2 .

Freitas and Rocha (2011) tested the acute toxicity of atrazine ( $99 \%$ pure) on a species of tropical cladoceran Pseudosida ramosa and found $\mathrm{LC}_{50}$ to be $17.1 \mathrm{mg} \mathrm{L}^{-1}$, also lower than the one recorded for the cladocerans usually used as testorganisms. However this value is also higher than the mean values recorded for the native species from our study, Macrothrix flabelligera $\left(12.4 \mathrm{mg} \mathrm{L}^{-1}\right)$ and Ceriodaphnia silvestrii (14.3 $\left.\mathrm{mg} \mathrm{L}^{-1}\right)$.

Direct comparisons of $\mathrm{LC}_{50}$ or $\mathrm{EC}_{50}$ values measured with several different freshwater invertebrates are somewhat hard to interpret because laboratory culture conditions usually differ with

Table 1. Mean values for $\mathrm{EC}_{50}-48 \mathrm{~h}$ of atrazine and $95 \%$ confidence intervals (inside parenthesis) for the cladocerans Ceriodaphnia silvestrii, Daphnia magna and Macrothrix flabelligera based on the results of three tests performed plus the estimated mean and standard deviation.

\begin{tabular}{cccc}
\hline Test Number & Daphnia magna $\left(\mathbf{m g ~ L}^{-1}\right)$ & Ceriodaphnia silvestrii $\left(\mathbf{m g ~ L}^{-1}\right)$ & Macrothrix flabelligera $\left(\mathbf{m g ~ L}^{-1}\right)$ \\
\hline 1 & $48.60(36.13-65.39)$ & $14.60(11.69-18.24)$ & $11.15(8.18-15.20)$ \\
2 & $53.44(35.31-80.88)$ & $12.62(10.33-15.43)$ & $15.43(11.96-19.91)$ \\
3 & $49.18(38.40-62.99)$ & $15.67(12.60-19.49)$ & $10.52(8.06-13.73)$ \\
$X \pm \mathrm{SD}$ & $50.41 \pm 2.64$ & $14.30 \pm 1.55$ & $12.37 \pm 2.67$ \\
\hline
\end{tabular}

Table 2. Acute toxicity values $\left(\mathrm{EC}_{50}\right)$ from the present study and from literature for some species of Cladocera exposed to atrazine.

\begin{tabular}{clcc}
\hline Test organism & Parameters & EC $_{50}\left(\mathbf{m g ~ L}^{-1}\right)$ & Reference \\
\hline Ceriodaphnia dubia & Immobilization - 48 h & 14.6 & Foster et al. (1998) \\
Ceriodaphnia silvestrii & Immobilization - 48 h & 14.3 & Present study \\
Daphnia carinata & Immobilization - 48 h & 24.6 & Phyu et al. (2004) \\
Daphnia magna & Immobilization - 48 h & 50.4 & Present study \\
& Immobilization - 48 h & 35.5 & Palma et al. (2008) \\
Daphnia pulex & Immobilization - 48 h & 36.5 & Hartman and Martin (1985) \\
Macrothrix flabelligera & Immobilization - 48 h & 12.4 & Present study \\
\hline
\end{tabular}


regard to photoperiod, temperature, exposure time and composition of culture media. In the case of atrazine, it is known that their toxicities can increase with increasing temperature (Folt et al., 1999; Mayasich et al., 1986). Therefore, differences in $\mathrm{LC}_{50}$ or $\mathrm{EC}_{50}$ values should be treated with caution when intrinsic differences in sensitivity are being compared among cladoceran species. Another important issue is the variation in the hardness of the reconstituted water used to culture the test species; thus, for $C$. silvestrii and $M$. flabelligera, the hardness was within the range stipulated in the ABNT (2005) guidelines for C. silvestrii (40 to 48 $\mathrm{mg} \mathrm{CaCO}_{3} \mathrm{~L}^{-1}$ ), much lower than the value used for D. magna (180 to $220 \mathrm{mg} \mathrm{CaCO}_{3} \mathrm{~L}^{-1}$ ). Therefore, further studies of the sensitivity of $C$. silvestrii and $M$. flabelligera are needed with respect to variations in the hardness of the water; in particular testing with the same toxic compound, should be done at high hardness, close to the standard values recommended by OECD (2004) for D. magna.

It is expected that if it was possible to test both species at the same water hardness, their sensitivity would probably become closer, since increasing water hardness usually decreases toxicity (Aragão and Araújo, 2008). These tests would nevertheless require the previous and gradual adaptation of each species to a range of hardness that is outside of the optimum in their tolerance curve.

In this study, the objective was to compare the susceptibility of the cladoceran species under the test conditions recommended in the test protocols. When these protocols are used to establish the maximum allowed levels of substances in local water quality criteria, comparisons performed under local conditions are valid. For example, in the tropical countries temperatures that vary from 23 to $27^{\circ} \mathrm{C}$ are recommended for the toxicity tests, (ABNT, 2010), while in temperate countries, protocols recommend a temperature varying from 18 to $22^{\circ} \mathrm{C}$ (OECD 2004, 2008). The maximum allowed levels for atrazine in a tropical country, established with the use of a temperate cladoceran species protocol, could therefore underestimate the toxicity of this chemical product to the tropical biota. Table 2 displays the reported values of $\mathrm{EC}_{50}$ $\left(\mathrm{mg} \mathrm{L}^{-1}\right)$ for cladocerans exposed to the herbicide atrazine. Comparing the $\mathrm{EC}_{50}-48 \mathrm{~h}$ values for atrazine obtained for $M$. flabelligera and $C$. silvestrii with those for other species, it can be seen that on the whole these two native species tested in the present study are more sensitive to atrazine than the cladoceran species tested in other studies.
The state of São Paulo is the greatest consumer of agrochemicals in Brazil (Armas et al., 2007). Over the years, triazines, and especially atrazine, have been used in great quantities in sugarcane plantations (Armas et al., 2005). In the sub-basin of the Corumbataí River (Piracicaba River basin), which encompasses a region of intensive sugarcane planting, atrazine concentrations that varied between 0.6 and $2.7 \mu \mathrm{g} \mathrm{L}^{-1}$ were found during the rainy summer (Armas et al., 2007). In Brazil, both the National Council for the Environment (CONAMA, 2005) and Ministry of Health-Brazil (2004) recommend a maximum level for atrazine of $2 \mu \mathrm{g} \mathrm{L} \mathrm{L}^{-1}$ in surface waters, in order to protect human health and aquatic life.

Although the actual concentrations found in Corumbataí River are above the maximum level permitted by law, they are about three to five orders of magnitude below the acute toxic level established in this study for D. magna, C. silvestrii and M. flabelligera. Apparently these species, in particular those occurring in Brazilian water bodies (M. flabelligera and C. silvestrii), would be protected from the acute effects of this herbicide. However, the indirect effects of atrazine on zooplankton organisms, such as alterations in the food sources should also be considered. As the primary mode of action of atrazine is the inhibition of photosynthesis, the direct effects of this compound in the water bodies occur mainly in the algal community (Dewey, 1986).

In many cases, native tropical species have been more sensitive to many compounds than many non-native temperate species, as it was observed for sodium and potassium by Freitas and Rocha, 2011 and for pesticides (diazinon and methyl parathion) and metals (chromium and mercury) by Do Hong et al. (2004). However, many water quality criteria in tropical regions are based on ecotoxicological tests with non-native species. This may lead to errors of interpretation when the maximum permitted levels for each particular toxic substance are established. To establish a realistic profile of the toxicity of the herbicide atrazine, we suggest that tests with a number of other native species belonging to zooplankton and also to other communities should be performed, using concentration ranges found in tropical freshwaters in order to get more realistic insights on the unintentional side-effects of herbicides on non-target freshwater microbiota. 


\section{Acknowledgments}

We are grateful to the Coordinating Committee for Improvement of Higher Education (CAPES) for the financial support and to anonymous referees that substantially contributed to this manuscript improvement.

\section{References}

ADEMA, DMM. 1978. Daphnia magna as a test animal in acute and chronic toxicity tests. Hydrobiologia, vol. 59, p. 125-134. http://dx.doi.org/10.1007/ BF00020773

AGUILAR-ALBEROLA, JA. and MESQUITAJOANES, F. 2012. Acute Toxicity Tests with Cadmium, Lead, Sodium Dodecyl Sulfate, and Bacillus thuringiensis on a Temporary Pond Ostracod. International Rev Hydrobiologia, vol. 97, no. 4, p. 375388. http://dx.doi.org/10.1002/iroh.201211497

American Society for Testing and Materials - ASTM. 1980. E-790-80: Standard practice for conducting acute toxicity test with fishes, macroinvertebrates and amphibians. Philadelphia: ASTM.

ARAGÃO, MA. and ARAÚJO, PA. 2008. Métodos de ensaio de toxicidade com organismos aquáticos. In ZAGATTO, PA. and BERTOLETTI, E., orgs. Ecotoxicologia aquática: princípios e aplicações. São Carlos: RiMa. p. 117-152.

ARMAS, ED., ROSIM-MONTEIRO, RT., AMÂNCIO, AV., CORREA, RML. and GUERCIO, MA. 2005. Uso de agrotóxicos em cana-de-açúcar na bacia do Rio Corumbataí e o risco de poluição hídrica. Química Nova, vol. 28, no. 6, p. 975-982. http:// dx.doi.org/10.1590/S0100-40422005000600008

ARMAS, ED., ROSIM-MONTEIRO, RT., ANTUNES, PM., SANTOS, MAPF., CAMARGO, PB. and ABAKERLI, RB. 2007. Diagnóstico espaço-temporal da ocorrência de herbicidas nas águas superficiais e sedimentos do Rio Corumbataí e principais afluentes. Quimica Nova, vol. 30, no. 5, p. 1119-1127. http:// dx.doi.org/10.1590/S0100-40422007000500013

Associação Brasileira de Normas Técnicas - ABNT. 2004. NBR 12713. Ecotoxicologia aquática - Toxicidade Aguda - Método de ensaio com Daphnia spp. (Cladocera, Crustacea). Rio de Janeiro: ABNT. p. 21.

Associação Brasileira de Normas Técnicas - ABNT. 2005. NBR 13373: Ecotoxicologia aquática - Toxicidade crônica - Método de ensaio com Ceriodaphnia spp. (Crustacea, Cladocera). Rio de Janeiro: ABNT. p. 15.

Associação Brasileira de Normas Técnicas - ABNT. 2010. NBR 13373: Ecotoxicologia aquática-Toxicidade crônica-Método de ensaio com Ceriodaphnia spp (Crustacea, Cladocera). Rio de Janeiro: ABNT. p. 18.

BAILLIEUL, M. and BLUST, R. 1999. Analysis of the swimming velocity of cadmium-stressed Daphnia magna. Aquatic Toxicology, vol. 44, p. 245-254. http://dx.doi.org/10.1016/S0166-445X(98)00080-0

BIESINGER, KE. and CHRISTENSEN, GM. 1972. Effects of various metals on survival, growth, reproduction, and metabolism of Daphnia magna. Journal of the Fisheries Research Board of Canada, vol. 29, no. 12, p. 1691-1700. http://dx.doi. org/10.1139/f72-269

BONAVENTURA, C. and JOHNSON, FM. 1997. Healthy environments for healthy people: bioremediation today and tomorrow. Environmental Health Perspectives, vol. 105, no. 1, p. 5-20. PMid:9114274 PMCid:PMC1470315.

Brazil. Ministry of Health. 2004. Decree no 518. Lays down procedures and responsibilities for the control and monitoring of the quality of water for human consumption and its standard of drinkability, and related matters. Diário Oficial da República Federativa do Brasil.

Conselho Nacional do Meio Ambiente - CONAMA. 2005. CONAMA resolution 357. Pronounces on the classification of water bodies and environmental directives in their respect, and also lays down conditions and Standards of effluent discharge, and other related questions. Diário Oficial da República Federativa do Brasil, mar.

DETTMERS, JM. and STEIN, RA. 1992. Food consumption by larval gizzard shad: zooplankton effects and implications for reservoir communities. Transactions of the American Fisheries Society, vol. 121, p. 494-507. http://dx.doi.org/10.1577/15488659(1992) $121<0494:$ FCBLGS>2.3.CO;2

DEWEY, SL. 1986. Effects of the herbicide atrazine on aquatic insect community structure and emergence. Ecology, vol. 67, no. 1, p. 148-162. http://dx.doi. org/10.2307/1938513

DO HONG, LC., BECKER-VAN SLOOTEN, K. and TARRADELLAS, J. 2004. Tropical ecotoxicity testing with Ceriodaphnia cornuta. Environmental Toxicology, vol. 19, p. 497-504. PMid:15352266. http://dx.doi.org/10.1002/tox.20055

FOLT, CL., CHEN, CY., MOORE, MV. and BURNAFORD, J. 1999. Synergism and antagonism among multiple stressors. Limnology and Oceanography, vol. 44, p. 864-877. http://dx.doi. org/10.4319/lo.1999.44.3_part_2.0864

FONSECA, AL. and ROCHA, O. 2004. The life cycle of Ceriodaphnia silvestrii Daday, 1902, a Neotropical endemic species (Crustacea, Cladocera, Daphnidae). Acta Limnologica Brasiliensia, vol. 16, p. 319-328.

FOSTER, S., THOMAS, M. and KORTH, W. 1998. Laboratory-derived acute toxicity of selected pesticides to Ceriodaphnia dubia. Australasian Journal of Ecotoxicology, vol. 4, p. 53-59.

FREITAS, EC. and ROCHA, O. 2011. Acute toxicity tests with the tropical cladoceran Pseudosida ramosa: 
the importance of using native species as test organisms. Archives of Environmental Contamination and Toxicology, vol. 60, p. 241-249. PMid:20464548. http://dx.doi.org/10.1007/s00244-010-9541-2

FREITAS, EC. and ROCHA, O. 2012. Acute and chronic effects of atrazine and sodium dodecyl sulfate on the tropical freshwater cladoceran Pseudosida ramosa. Ecotoxicology, vol. 21, p. 13471357. PMid:22434152. http://dx.doi.org/10.1007/ s10646-012-0888-1

GILLIOM, RJ., BARBASH, JE., CRAWFORD, CG., HAMILTON, PA., MARTIN, JD., NAKAGAKI, N., NOWELL, LH., SCOTT, JC., STACKELBERG, PE., THELIN, GP. and WOLOCK, DM., 2006. The quality of our nation's waters. Pesticides in the nation's streams and ground water, 1992-2001. Reston: US Geological Survey.

GRÜTZMACHER, DD., GRÜTZMACHER, AD., AGOSTINETTO, D., LOECK, AE., ROMAN, R., PEIXOTO, SC. and ZANELLA, R., 2008. Monitoramento de agrotóxicos em dois mananciais hídricos no sul do Brasil. Revista Brasileira de Engenharia Agricola e Ambiental, vol. 12, no. 6, p. 632-637. http://dx.doi.org/10.1590/S141543662008000600010

GÜNTZEL, AM., MATSUMURA-TUNDISI, T. and ROCHA, O. 2004. Macrothrix flabelligera, a newlyrecorded Cladocera Macrothricidae in Brazilian freshwaters. Brazilian Journal of Biology, vol. 64, no. 2, p. 221-226. PMid:15462294. http://dx.doi. org/10.1590/S1519-69842004000200006

HAMILTON, MA., RUSSO, RC. and THURFTON, RB. 1977. Trimmed Spearman-Karber method for estimating median lethal concentration in toxicity bioassays. Environmental Science and Technology, v. 11, no. 7, p. 714-719. http://dx.doi.org/10.1021/ es60130a004

HARTMAN, NK. and MARTIN, DB. 1985. Effects of four agricultural pesticides on Daphnia pulex, Lemma minor and Potamogeton pectinatus. Bulletin of Environmental Contamination and Toxicology, vol. 5, p. 646-651.

KOIVISTO, S. 1995. Is Daphnia magna an ecologically representative zooplankton species in toxicity tests? Environmental Pollution, vol. 90, no. 2, p. 263-267. http://dx.doi.org/10.1016/0269-7491(95)00029-Q

LILIUS, H., HASTBACKA, T. and ISOMAA, B. 1995. A comparison of the toxicity of 30 reference chemicals to Daphnia magna and Daphnia pulex. Environmental Toxicology and Chemistry, vol. 14, p. 2085-2088.

MAYASICH, JM., KARLANDER, EP. and TERLIZZI JUNIOR, DE. 1986. Growth responses of Nannochloris oculata Droop and Phaeodactylum tricornutum Bohlin to the herbicide atrazine as influenced by light intensity and temperature. Aquatic Toxicology, vol. 8, p. 175-184. http://dx.doi. org/10.1016/0166-445X(86)90063-9
MITCHELL, SE., HALVES, J. and LAMPERT, W. 2004. Coexistence of similar genotypes of Daphnia magna in intermittent populations: response to thermal stress. Oikos, vol. 106, no. 3, p. 469-478. http:// dx.doi.org/10.1111/j.0030-1299.2004.13113.x

MÜLLER, H. 1972. Wachstum and phosphatbedarf von Nitzschia actinastroides (Lemn.) v. Goor in statischer und homokontiuierliecher kultur unter phosphatlimitierung. Archiv fur Hydrobiologie Supplement, vol. 38, p. 399-484.

Organization for Economic Cooperation and Development - OECD. 2004. Guideline for testing of chemicals. Daphnia sp., acute immobilization test. OECD 202. Paris: OECD.

Organization for Economic Cooperation and Development - OECD. 2008. Guidelines for testing of chemicals. Daphnia magna reproduction test. OECD 211. Paris OECD.

PALMA, P., PALMA, VL., FERNANDES, RM., SOARES, AMVM. and BARBOSA, IR. 2008. Acute toxicity of atrazine, endosulfan sulphate and chlorpyrifos to Vibrio fischeri, Thamnocephalus platyurus and Daphnia magna, relative to their concentrations in surface waters from the Alentejo region of Portugal. Bulletin of Environmental Contamination and Toxicology, vol. 81, no. 5, p. 485489. PMid:18777155. http://dx.doi.org/10.1007/ s00128-008-9517-3

PÉREZ, J., DOMINGUES, I., SOARES, AM. and LOUREIRO, S. 2011. Growth rate of Pseudokirchneriella subcapitata exposed to herbicides found in surface waters in the Alqueva reservoir (Portugal): a bottom-up approach using binary mixtures. Ecotoxicology, vol. 20, no. 6, p. 1167 1175. PMid:21448621. http://dx.doi.org/10.1007/ s10646-011-0661-x

PHYU, YL., WARNE, MJ. and LIM, RP. 2004. Toxicity of atrazine and molinate to the cladoceran Daphnia carinata and the effect of river water and bottom sediment on their bioavailability. Archives of Environmental Contamination and Toxicology, vol. 46, p. 308-315. PMid:15195802.

SANDERSON, JT., SEINEN, W., GIESY, JP. and VAN DEN BERG, M. 2000. 2-chloro- S-triazine herbicides induce aromatase (CYP-19) activity in H295R human adrenocortical carcinoma cells: a novel mechanism for estrogenicity. Toxicological Sciences, vol. 54, p. 121-127.

TAYLOR, EJ., MAUND, SJ. and PASCOE, D. 1991. Toxicity of four common pollutants to the freshwater macroinvertebrates Chironomus riparius Meigen (Insecta:Diptera) and Gammarus pulex (L.) (Crustacea: Amphipoda). Archives of Environmental Contamination and Toxicology, vol. 21, no. 3, p. 3716. PMid:1719943. http://dx.doi.org/10.1007/ BF01060358 
TRAYLER, KM. and DAVIS, JA. 1996. Sensitivity of Daphnia carinata sensu lato to the insect growth regulator, pyriproxyfen. Ecotoxicology and Environmental Safety, vol. 33, no. 2, p. 154156. PMid:8723752. http://dx.doi.org/10.1006/ eesa.1996.0019

WAN, MT., BUDAY, C., SCHROEDER, G., KUO, J. and PASTERNAK, J. 2006. Toxicity to Daphnia magna, Hyalella azteca, Oncorhynchus kisutch, Oncorhynchus mykiss, Oncorhynchus tshawytscha, and Rana catesbeiana of Atrazine, Metolachlor,
Simazine, and Their Formulated Products. Bulletin of Environmental Contamination and Toxicology, vol. 76, p. 52-58. PMid:16404660. http://dx.doi. org/10.1007/s00128-005-0888-4

WIGHTWICK, A. and ALLINSON, G. 2007. Pesticide residues in Victorian waterways: a review. Australasian Journal of Ecotoxicology, vol. 3, p. 91-112.

WINNER, RW. and FARREL, MP. 1976. Acute and Chronic Toxicity of Copper to four Species of Daphnia. Journal of the Fisheries Research Board of Canada, vol. 33, p. 1685-1691. http://dx.doi. org/10.1139/f76-215

Received: 20 August 2013

Accepted: 07 April 2014 